\title{
EDITORIAL
}

\section{In 2035, will all bacteria be multidrug-resistant? No}

\author{
François Barbier ${ }^{{ }^{*}}$, Jeffrey Lipman ${ }^{2,3,4}$ and Marc J. M. Bonten ${ }^{5}$
}

(C) 2016 Springer-Verlag Berlin Heidelberg and ESICM

The spread of multidrug-resistant (MDR) bacteria has reached a threatening level. Extended-spectrum betalactamase-producing enterobacteriaceae (ESBLE) are now endemic in many hospitals worldwide as well as in the community, while resistance rates continue to rise steadily in Acinetobacter baumannii and Pseudomonas aeruginosa [1]. Even more alarming is the dissemination of carbapenemase-producing enterobacteriaceae $(\mathrm{CPE})$, causing therapeutic and organizational problems in hospitals facing outbreaks or endemicity. This context could elicit serious concerns for the coming two decades; nevertheless, effective measures exist to stop the amplification of the problem and several axes of prevention remain to be fully exploited, leaving room for realistic hopes, at least for many parts of the world.

Conceptually, there are three mechanisms of increasing and two for decreasing the prevalence of carriage with MDR bacteria in healthcare settings, including in the intensive care unit (ICU). First, there is a certain fraction of patients colonized when admitted; second, MDR bacteria are selected within a patient as a result of selective pressure of antibiotics; and third, MDR bacteria are transferred between patients, either through healthcare workers or contaminated inanimate surfaces. The prevalence can decrease by discharging colonized patients (and admitting non-colonized patients) or by eradicating carriage of MDR bacteria. For the current debate, we will ignore the last two options and focus on the possibilities

*Correspondence: barbierfrancois.chro@gmail.com;

francois.barbier@chr-orleans.fr

${ }^{1}$ Medical Intensive Care Unit, La Source Hospital - CHR Orléans, Orléans,

France

Full author information is available at the end of the article

For contrasting viewpoints, please go to doi:10.1007/s00134-016-4310-y and doi:10.1007/s00134-016-4343-2. to reduce importation, selection, and transmission of MDR bacteria (Table 1).

The strongest arguments for our position are that, even in 2035, a conceivable proportion of ICU patients will be admitted directly from the community (or after little healthcare exposure) and that MDR bacteria will still not be widely prevalent outside the hospital setting. Thus far, there is reason to believe that MDR bacteria do not spread easily in healthy populations with low antibiotic selective pressure. For instance, a large abundance of livestock-associated methicillin-resistant Staphylococcus aureus (MRSA) in the agricultural industry has not created a clinically relevant prevalence of MRSA carriage in open populations [2]. Furthermore, in many countriesincluding in Europe-the prevalence of colonization with ESBLE among healthy subjects is around 5-10 \%, and appears not to increase [3]. It is highly unlikely that, in such countries, CPE will be more successful in similar conditions. A prerequisite for maintaining this situation is that antibiotic use in primary care is either maintained at current levels or reduced by using regional or nationwide antibiotic restriction campaigns [4]. Eliminating unnecessary or inappropriate prescriptions in ambulatory patients is now strongly advocated in most action plans targeting bacterial resistance [5]; as a result, a large proportion of ICU patients will still be admitted without carrying MDR bacteria.

As antimicrobial consumption represents a major driver of bacterial resistance in the healthcare setting [4], avoiding antibiotic overuse-or misuse-stands as the most urgent action to control the dissemination of MDR pathogens. In this regard, infection prevention policies appear essential to contain the level of selection pressure in hospitalized patients [6]. Furthermore, antimicrobial stewardship programs (ASPs) may improve the quality of antibiotic prescription practices through a bundle of measures, including institutional restrictions for the use

\section{Springer}


Table 1 Ten pivotal measures to avoid a situation of pan-drug resistance in the intensive care unit in 2035

\begin{tabular}{|c|c|c|}
\hline Actions & Area of implementation & Objective \\
\hline Containment of antimicrobial use in primary care & Community & \multirow{3}{*}{$\begin{array}{l}\text { Reduce importation of MDR bacteria (patients admitted from } \\
\text { the community) by lowering antibiotic selection pressure } \\
\text { outside the healthcare setting }\end{array}$} \\
\hline $\begin{array}{l}\text { Strict control of antibiotic consumption in veterinary medi- } \\
\text { cine and agricultural/aquacultural industries }\end{array}$ & Community & \\
\hline $\begin{array}{l}\text { Prevention of environmental contamination with MDR } \\
\text { bacteria }\end{array}$ & Community & \\
\hline Universal compliance to hygiene guidelines & Hospital wards and ICU & \multirow{2}{*}{$\begin{array}{l}\text { Reduce importation (patients transferred from wards) and } \\
\text { prevent cross-transmission of MDR bacteria }\end{array}$} \\
\hline $\begin{array}{l}\text { Screening for carriage of MDR bacteria and implementation } \\
\text { of isolation precautions in identified carriers }\end{array}$ & Hospital wards and ICU & \\
\hline $\begin{array}{l}\text { Enhanced strategies for the diagnosis of bacterial } \\
\text { infection to avoid unnecessary antibiotic prescriptions }\end{array}$ & Hospital wards and ICU & \multirow{4}{*}{$\begin{array}{l}\text { Preserve currently available broad-spectrum antibiotics and } \\
\text { prevent the emergence of resistance by lowering antibiotic } \\
\text { selection pressure in hospitalized patients (antibiotic } \\
\text { stewardship initiatives) }\end{array}$} \\
\hline $\begin{array}{l}\text { Development of accurate tools to narrow the spectrum } \\
\text { of empirical therapy }\end{array}$ & Hospital wards and ICU & \\
\hline $\begin{array}{l}\text { Systematic reassessment of empirical therapy and de- } \\
\text { escalation whenever possible }\end{array}$ & Hospital wards and ICU & \\
\hline $\begin{array}{l}\text { Shortening of antimicrobial therapy (e.g., PCT-driven } \\
\text { algorithm) whenever possible }\end{array}$ & Hospital wards and ICU & \\
\hline $\begin{array}{l}\text { Large-scale programs to promote and speed up the } \\
\text { development of novel antimicrobial agents }\end{array}$ & Global & Offer new options to treat MDR bacteria \\
\hline
\end{tabular}

MDR multidrug-resistant, ICU intensive care unit, $P C T$ procalcitonin

of certain broad-spectrum agents that markedly foster resistance (notably carbapenems and fluoroquinolones) and scheduled feedback in an attempt to sustain behavioral changes on a long-term basis [5]. The first step is to more accurately define the diagnosis of bacterial infections, thus limiting unnecessary selection pressure in patients with systemic inflammatory response but no bacterial sepsis. Low plasma levels of procalcitonin (PCT) can rule out the need for antimicrobial prescription in ambulatory patients with respiratory tract infections [7], and whether PCT may be safely used to guide not starting antibiotics in septic critically ill patients deserves further investigations. Other novel diagnostic approaches based on rapid molecular assays also have potential to identify critically ill patients who actually require antibiotics [8]. Once the diagnosis of bacterial infection is deemed likely, a challenging dilemma is to ensure adequate empirical antimicrobial coverage with the narrowest spectrum of activity, a problem in patient populations with high colonization rates of MDR pathogens. Indeed, ESBLE carriage in otherwise uninfected critically ill patients has been associated with a three-fold increase in the empirical use of carbapenems during the ICU stay when compared to non-carriers [9]. Yet, documented absence of carriage might be used to withhold maximum broad-spectrum antibiotics in case of infection [10], and the development of rapid diagnostic tools-including phenotypic methods, mass spectrometry, or PCR-based assays - for earlier identification of pathogens and resistance patterns offers promising perspectives to target narrower-spectrum empirical therapy [6].
Reassessment of antibiotic therapy with predefined strategies for de-escalation forms another pivotal aspect of ASPs. De-escalation can be performed safely in critically ill patients [11], but only when relevant culture results are available. Therefore, de-escalation can only be meaningfully used to control antibiotic resistance if microbiological diagnostics are applied systematically. Next, ASP components targeting pharmacokinetic/ pharmacodynamic parameters (e.g., high-dose regimens, extended $\beta$-lactam infusion, or therapeutic drug monitoring) could conceivably prevent the emergence of resistant mutants at the infection site by avoiding underdosing and sublethal concentrations [12]. Also, antibiotic courses can often be safely shortened [6], which is essential as even a couple of days of antibiotic administration increases the likelihood of colonization with resistant Gram-negative bacilli in ICU patients [1]. The reliability of PCT-driven algorithms to customize treatment duration in patients with rapid organ failure resolution is now well established, enabling ICU physicians to reduce antimicrobial exposure without deleterious outcomes $[7,13]$.

Although further studies remain necessary to appraise the ecological benefits of ASPs, evidence already exists that reducing the overall volume of broad-spectrum beta-lactams and fluoroquinolones consumption in a given hospital can significantly decrease local resistance rates in enterobacteriaceae and non-fermenting Gramnegative bacilli, including in the ICU [14].

Hygiene compliance and the implementation of isolation precautions for identified carriers are key measures to prevent cross-transmission of MDR bacteria 
in hospitalized patients, especially in the ICU [6]. For instance, a nearly two-fold decrease in the incidence of MRSA infections was observed in a large network of French university-affiliated hospitals over a 15-year period following the launch of a multifaceted program comprising the promotion of alcohol-based hand rubbing, carriage surveillance, barrier precautions, training, and feedback [15]. In another study conducted in 13 European ICUs, improving hand hygiene in combination with daily chlorhexidine bathing was associated with reduced MRSA acquisition rates [16]. Nowadays, a vast majority of hospital staff members are confronted with multidrug resistance in their routine practice, and one could hope that this situation will further raise awareness about the problem, thereby easing the implementation and acceptation of constraining prevention campaigns in the years to come.

Finally, large-scaled initiatives are currently employed to facilitate more rapid development and clinical evaluation of new antimicrobial agents [17]. These efforts, plus the use of efficient ASPs [5], improved infection diagnostics [8], earlier targeted narrow-spectrum antibiotic use [6], better dosing strategies [12], shorter antibiotic duration $[18,19]$, adequate hygiene policies [6], and controlled antibiotic use outside the healthcare setting [4] further strengthen our position that effective treatments will remain available in 2035 .

\section{Author details \\ ${ }^{1}$ Medical Intensive Care Unit, La Source Hospital - CHR Orléans, Orléans, France. ${ }^{2}$ University of Queensland, Brisbane, Australia. ${ }^{3}$ Queensland University of Technology, Brisbane, Australia. ${ }^{4}$ University of the Witwatersrand, Johan- nesburg, South Africa. ${ }^{5}$ Department of Medical Microbiology, Julius Centre for Health Sciences and Primary Care, University Medical Centre Utrecht, Utrecht, The Netherlands.}

\section{Acknowledgments}

None.

\section{Compliance with ethical standards}

\section{Funding}

None.

\section{Conflicts of interest}

FB: MSD (advisory board, current), Pfizer (conference invitations, past). JL: MSD (advisory board, current). MB: no potential conflict of interest to declare.

Received: 31 March 2016 Accepted: 2 April 2016

Published online: 18 April 2016

\section{References}

1. Ruppé E, Woerther PL, Barbier F (2015) Mechanisms of antimicrobial resistance in Gram-negative bacilli. Ann Intensive Care 5:21

2. den Heijer CD, van Bijnen EM, Paget WJ, Pringle M, Goossens H, Bruggeman CA, Schellevis FG, Stobberingh EE (2013) Prevalence and resistance of commensal Staphylococcus aureus, including methicillin-resistant $S$ aureus, in nine European countries: a cross-sectional study. Lancet Infect Dis 15(5):409-415
3. Platteel TN, Leverstein-van Hall MA, Cohen Stuart JW, Thijsen SF, Mascini EM, van Hees BC, Scharringa J, Fluit AC, Bonten MJ (2015) Predicting carriage with extended-spectrum beta-lactamase-producing bacteria at hospital admission: a cross-sectional study. Clin Microbiol Infect 21(2):141-146

4. Holmes AH, Moore LS, Sundsfjord A, Steinbakk M, Regmi S, Karkey A, Guerin PJ, Piddock $L$ (2016) Understanding the mechanisms and drivers of antimicrobial resistance. Lancet 387(10014):176-187

5. Roca I, Akova M, Baquero F, Carlet J, Cavaleri M, Coenen S, Cohen J, Findlay D, Gyssens I, Heure OE, Kahlmeter G, Kruse H, Laxminarayan R, Liebana E, Lopez-Cerero L, MacGowan A, Martins M, Rodriquez-Bano J, Rolain JM, Segovia C, Sigauque B, Taconelli E, Wellington E, Vila J (2015) The global threat of antimicrobial resistance: science for intervention. New Microbes New Infect 6:22-29

6. Bassetti M, De Waele JJ, Eggimann P, Garnacho-Montero J, Kahlmeter G, Menichetti F, Nicolau DP, Paiva JA, Tumbarello M, Welte T, Wilcox M, Zahar $J R$, Poulakou G (2015) Preventive and therapeutic strategies in critically ill patients with highly resistant bacteria. Intensive Care Med 41 (5):776-795

7. Schuetz P, Briel M, Christ-Crain M, Stolz D, Bouadma L, Wolff M, Luyt CE, Chastre J, Tubach F, Kristoffersen KB, Wei L, Burkhardt O, Welte T, Schroeder S, Nobre V, Tamm M, Bhatnagar N, Bucher HC, Mueller B (2012) Procalcitonin to guide initiation and duration of antibiotic treatment in acute respiratory infections: an individual patient data meta-analysis. Clin Infect Dis 55(5):651-662

8. McHugh L, Seldon TA, Brandon RA, Kirk JT, Rapisarda A, Sutherland AJ, Presneill JJ, Venter DJ, Lipman J, Thomas MR, Klein Klouwenberg PM, van Vught L, Scicluna B, Bonten M, Cremer OL, Schultz MJ, van der Poll T, Yager TD, Brandon RB (2015) A molecular host response assay to discriminate between sepsis and infection-negative systemic inflammation in critically ill patients: discovery and validation in independent cohorts. PLoS Med 12(12):e1001916

9. Barbier F, Pommier C, Essaied W, Garrouste-Orgeas M, Schwebel C, Ruckly S, Dumenil AS, Lemiale V, Mourvillier B, Clec'h C, Darmon M, Laurent V, Marcotte G, Lucet JC, Souweine B, Zahar JR, Timsit JF (2016) Colonization and infection with extended-spectrum betalactamase-producing Enterobacteriaceae in ICU patients: what impact on outcomes and carbapenem exposure? J Antimicrob Chemother 71(4):1088-1097

10. Bruyere R, Vigneron C, Bador J, Aho S, Toitot A, Quenot JP, Prin S, Emmanuel Charles P (2016) Significance of prior digestive colonization with extended-spectrum beta-lactamase-producing Enterobacteriaceae in patients with ventilator-associated pneumonia. Crit Care Med 44(4):699-706

11. Tabah A, Cotta MO, Garnacho-Montero J, Schouten J, Roberts JA, Lipman J, Tacey M, Timsit JF, Leone M, Zahar JR, De Waele JJ (2016) A systematic review of the definitions, determinants, and clinical outcomes of antimicrobial de-escalation in the intensive care unit. Clin Infect Dis 62(8):1009-1017

12. Bergen P, Bulitta J, Kirkpatrick C, Rogers K, McGregor M, Wallis S, Paterson DL, Lipman J, Roberts J, Landersdorfer C (2016) Effect of different renal function on anti-bacterial effects of piperacillin against Pseudomonas aeruginosa evaluated via the hollow fibre infection model and mechanismbased modelling. J Antimicrob Chemother (in press)

13. de Jong E, van Oers JA, Beishuizen A, Vos P, Vermeijden WJ, Haas LE, Loef BG, Dormans T, van Melsen GC, Kluiters YC, Kemperman H, van den Elsen MJ, Schouten JA, Streefkerk JO, Krabbe HG, Kieft H, Kluge GH, van Dam VC, van Pelt J, Bormans L, Bokelman Otten M, Reidinga AC, Endeman H, Twisk JW, van de Garde EMW, de Smet AM, Kesecioglu J, Girbes AR, Nijsten MW, de Lange DW (2016) Efficacy and safety of procalcitonin guidance in reducing the duration of antibiotic treatment in critically ill patients: a randomised, controlled, open-label trial. Lancet Infect Dis. doi:10.1016/S1473-3099(16)00053

14. Kaki R, Elligsen M, Walker S, Simor A, Palmay L, Daneman N (2011) Impact of antimicrobial stewardship in critical care: a systematic review. J Antimicrob Chemother 66(6):1223-1230

15. Jarlier V, Trystram D, Brun-Buisson C, Fournier S, Carbonne A, Marty L, Andremont A, Arlet G, Buu-Hoi A, Carlet J, Decre D, Gottot S, Gutmann L, Joly-Guillou ML, Legrand P, Nicolas-Chanoine MH, Soussy CJ, Wolf M, Lucet JC, Aggoune M, Brucker G, Regnier B (2010) Curbing methicillinresistant Staphylococcus aureus in 38 French hospitals through a 15-year institutional control program. Arch Intern Med 170(6):552-559 
16. Derde LP, Cooper BS, Goossens H, Malhotra-Kumar S, Willems RJ, Gniadkowski M, Hryniewicz W, Empel J, Dautzenberg MJ, Annane D, Aragao I, Chalfine A, Dumpis U, Esteves F, Giamarellou H, Muzlovic I, Nardi G, Petrikkos GL, Tomic V, Marti AT, Stammet P, Brun-Buisson C, Bonten MJ (2014) Interventions to reduce colonisation and transmission of antimicrobialresistant bacteria in intensive care units: an interrupted time series study and cluster randomised trial. Lancet Infect Dis 14(1):31-39

17. Kostyanev T, Bonten MJ, O'Brien S, Steel H, Ross S, Francois B, Tacconelli E, Winterhalter M, Stavenger RA, Karlen A, Harbarth S, Hackett J, Jafri HS, Vuong C, MacGowan A, Witschi A, Angyalosi G, Elborn JS, deWinter R, Goossens H (2016) The Innovative Medicines Initiative's New Drugs for Bad Bugs programme: european public-private partnerships for the development of new strategies to tackle antibiotic resistance. J Antimicrob Chemother 71(2):290-295
18. Armand-Lefevre L, Angebault C, Barbier F, Hamelet E, Defrance G, Ruppé E, Bronchard R, Lepeule R, Lucet JC, El Mniai A, Wolff M, Montravers P, Plesiat P, Andremont A (2013) Emergence of imipenem-resistant Gramnegative bacilli in intestinal flora of intensive care patients. Antimicrob Agents Chemother 57(3):1488-1495

19. De Santis V, Gresoiu M, Corona A, Wilson AP, Singer M (2015) Bacteraemia incidence, causative organisms and resistance patterns, antibiotic strategies and outcomes in a single university ICU: continuing improvement between 2000 and 2013. J Antimicrob Chemother 70(1):273-278 